\title{
PENGEMBANGAN DAN EFEKTIFITAS BAHAN AJAR LAJU REAKSI DENGAN PENDEKATAN INKUIRI TERBIMBING TERHADAP KEMAMPUAN BERPIKIR TINGKAT TINGGI PESERTA DIDIK SMA
}

\author{
Diah Purwaningtyas \\ SMAN 3 Malang Jawa Timur \\ Email: diah.purwaningtyas.75@gmail.com
}

\begin{abstract}
Abstrak
Tujuan penelitian pengembangan adalah menghasilkan bahan ajar materi laju reaksi dengan pendekatan Inkuiri Terbimbing yang layak dan efektif diterapkan pada pembelajaran kimia serta mengetahui persepsi peserta didik terhadap bahan ajar yang dikembangkan. Metode pengembangan bahan ajar menggunakan model 4D dari Thiagarajan dkk (1974), tetapi tanpa tahap keempat. Hasil penilaian para ahli menyatakan bahwa bahan ajar yang dikembangkan dinyatakan sangat layak pada aspek isi dan media serta layak pada aspek keterbacaan. Pada uji efektivitas menunjukkan bahwa bahan ajar tersebut lebih efektif dalam meningkatkan kemampuan berpikir tingkat tinggi peserta didik dibanding bahan ajar lain. Secara umum peserta didik memberikan respons positif terhadap bahan ajar hasil pengembangan.
\end{abstract}

Kata kunci: Bahan ajar laju reaksi, SMA, inkuiri terbimbing, kemampuan berpikir tingkat tinggi

\section{Pendahuluan}

Kurikulum 2013 menekankan pada pendekatan saintifik. Pembelajaran yang menekankan pada pendekatan saintifik adalah pembelajaran yang mengembangkan pengetahuan, kemampuan berpikir dan keterampilan menggunakan pengetahuan peserta didik melalui interaksi langsung dengan sumber belajar yang dirancang dalam RPP. Pendekatan saintifik yang diharapkan dalam pembelajaran adalah pendekatan yang berbasis pada proses keilmuan melalui kegiatan mengamati, menanya, mengumpulkan informasi atau mencoba, menalar atau mengasosiasi, serta mengomunikasikan (Kemendikbud, 2013).

Salah satu pendekatan pembelajaran yang menekankan pada proses saintifik adalah pendekatan pembelajaran inquiry learning. Pembelajaran dengan pendekatan inkuiri dapat mendorong peserta didik untuk terlibat aktif melakukan percobaan, menggali pengetahuan dan informasi secara langsung sampai memungkinkan mereka menemukan konsep-konsep dan prinsip-prinsip yang berguna bagi mereka sendiri. Proses dalam pembelajaran ini menonjolkan ketrampilan proses dan sikap ilmiah yang membuat peserta didik dapat menemukan sendiri konsep/prinsip sehingga lebih memudahkan dalam mengingat dibandingkan dengan menghafal seperti yang terjadi pada pembelajaran konvensional. Proses inkuiri ilmiah bertujuan menumbuhkan kemampuan berpikir, bekerja dan bersikap ilmiah serta berkomunikasi sebagai salah satu kecakapan hidup. Pendekatan pembelajaran inkuiri terbimbing dapat digunakan sebagai alternatif untuk meningkatkan motivasi belajar dan kemampuan berpikir tingkat tinggi peserta didik.

Kimia merupakan salah satu materi yang diberikan di SMA kelompok peminatan IPA. Materi laju reaksi yang terdapat didalamnya merupakan materi yang bersifat abstrak, sehingga untuk mempelajarinya diperlukan penjelasan secara makroskopik, submikroskopik dan simbolik. Berdasarkan penelitian-penelitian sebelumnya masih banyak ditemukan adanya miskonsepsi pada materi tersebut. Pemahaman peserta didik pada konsep laju reaksi, konsep orde reaksi, dan konsep faktor-faktor yang mempengaruhi laju reaksi tergolong cukup, sedangkan pemahaman peserta didik pada konsep teori tumbukan tergolong rendah (Prananda, 2013). 
Salah satu usaha yang dapat dilakukan untuk mencegah adanya kesalahan konsep tersebut yaitu dengan pemilihan strategi dalam menyajikan materi tersebut. Hasil pembelajaran kimia di SMA selain dipengaruhi oleh strategi pembelajaran juga dipengaruhi beberapa faktor diantaranya padatnya materi, keterbatasan waktu, minat peserta didik dan proses pembelajaran. Kenyataan di lapangan menunjukkan bahwa umumnya guru SMA memberikan materi kimia hanya dalam bentuk konsep dasar secara teoritis saja. Konsep dasar ilmu kimia tersebut diberikan secara terpisah tanpa menghubungkan langsung dengan kehidupan sehari-hari, sehingga peserta didik beranggapan bahwa mata pelajaran kimia kurang bermanfaat untuk memecahkan masalah di kehidupan nyata.

Permasalahan pembelajaran kimia di SMA juga dikarenakan oleh keterbatasan bahan ajar kimia yang dapat memenuhi tuntutan ketercapaian kompetensi yang diinginkan. Analisis awal yang dilakukan menunjukkan bahwa bahan ajar yang dipakai selama ini secara konsep dasar sangat bagus, tetapi penyajian materi khususnya laju reaksi belum menunjukkan adanya keterkaitan antara materi kimia dengan kehidupan nyata.

Bahan ajar yang bersifat teoritis dan kurang terintegrasi dengan kehidupan nyata diduga menjadi penyebab rendahnya minat dan motivasi peserta didik dalam pembelajaran kimia, sehingga mengakibatkan prestasi belajar peserta didik menjadi rendah. Oleh karena itu, keberadaan bahan ajar yang dapat mengarahkan peserta didik untuk mengonstruksi konsepnya secara mandiri serta terintegrasi dalam kehidupan nyata sangat dibutuhkan oleh peserta didik dan guru. Pendekatan inkuiri terbimbing dapat dipilih sebagai usaha untuk memperbaiki pembentukan konsep peserta didik sehingga akan meningkatkan ketertarikan peserta didik dalam pembelajaran. pendekatan inkuiri menunjukkan bahwa strategi inkuiri efektif digunakan untuk meningkatkan hasil belajar peserta didik meliputi peningkatan pengetahuan, pemahaman konseptual, dan meningkatkan kemampuan berpikir tingkat tinggi (Vlassi \& Karaliota, 2013).
Berdasarkan fakta tersebut maka perlu dikembangkan bahan ajar untuk pembelajaran kimia di SMA dengan spesifikasi tersebut di atas. Hal ini perlu karena bahan ajar merupakan salah satu jenis sumber belajar yang efektif dan efisien serta dapat dijadikan referensi baku untuk mata pelajaran tertentu (Akbar, 2013). Bahan ajar yang berkualitas harus memenuhi prinsip relevansi dengan kurikulum, prinsip konsistensi dengan kompetensi dasar yang digunakan dan prinsip kecukupan materi (Gafur, 1994). Selain itu, belum ada bahan ajar materi laju reaksi untuk SMA dengan menggunakan pendekatan inkuiri terbimbing.

\section{Landasan Teori}

Bahan ajar merupakan salah satu media yang dapat membantu kelancaran dan keberhasilan proses pembelajaran. Bahan ajar memudahkan guru untuk mengarahkan pembelajaran sedangkan bagi siswa sebagai pedoman proses dalam pembelajaran. Menurut Depdiknas (2008), bahan ajar berfungsi sebagai (1) pedoman bagi Guru dan siswa untuk mengarahkan semua aktivitasnya dalam proses pembelajaran, sekaligus merupakan substansi kompetensi yang seharusnya diajarkan oleh guru dan harus dipelajari dan dikuasai oleh siswa; dan (2) alat evaluasi pencapaian atau penguasaan hasil pembelajaran.

Dengan didasari oleh penjelasan dari Depdiknas tersebut, selayaknya pembelajaran laju reaksi sebaiknya juga menggunakan bantuan bahan ajar. Dari hasil penelitian pengembangan bahan ajar yang dilakukan oleh Fitria (2012) didapatkan hasil bahwa bahan ajar hendaknya (1) meningkatkan keaktifan siswa karena modul yang dikembangkan disajikan secara komunikatif dua arah; (2) mengefektifkan waktu pembelajaran, karena modul dapat mencakup tingkat kemampuan siswa yang berbeda-beda meliputi kecerdasan serta kecepatan belajar, sehingga waktu belajar menjadi lebih fleksibel; dan (3) lebih memotivasi dan meningkatkan minat siswa untuk mendalami materi karena modul dilengkapi dengan gambar, percobaan, serta aplikasi materi dalam kehidupan seharihari. 
Menurut Bloom et al (1956), kemampuan berpikir manusia dibedakan menjadi dua yaitu kemampuan berpikir tingkat tinggi dan kemampuan berpikir tingkat rendah. Kemampuan berpikir tingkat rendah mencerminkan hafalan atau melakukan perhitungan sederhana seperti penjumlahan, pembagian, perkalian, menguadratkan angka atau menemukan logaritma suatu angka. Kemampuan berpikir tingkat tinggi sesuai dengan taksonomi Bloom yaitu kemampuan berpikir pada ranah menganalisis, mensintesis, dan mengevaluasi. Kemampuan pembelajaran tingkat tinggi dapat dikembangkan dengan pembelajaran inquiry. Pembelajaran inkuiri memiliki beberapa tingkat atau level. Llewellyn (2013) mengelompokkan inkuiri menjadi 4 tingkatan berdasarkan tingkat dominasi peran guru dan siswa, yaitu inkuiri demonstrasi (demonstrated inquiry), inkuiri terstruktur (structured inquiry), inkuiri terbimbing (guided inquiry), dan imkuiri penuh (full inquiry). Sintaks inkuiri terbimbing yang digunakan dalam penelitian ini adalah sintaks inkuiri terbimbing Llewellyn (2013) yang dimodifikasi.

Berdasarkan pertimbangan di atas, perlu adanya bahan ajar materi laju reaksi dengan pendekatan inkuiri terbimbing untuk menunjang keberhasilan pembelajaran. Bahan ajar hasil pengembangan diharapkan dapat membuat siswa belajar dengan lebih mudah karena dibimbing oleh guru melalui tahapantahapan dalam bahan ajar tersebut, dan dapat mengembangkan kemampuan berpikir tingkat tinggi.

Tujuan dari penelitian ini adalah pengembangan bahan ajar kimia materi laju reaksi dengan pendekatan inkuiri terbimbing untuk peserta didik SMA dengan cara menguji efektifitas bahan ajar kimia materi laju reaksi tersebut dan mengetahui persepsi peserta didik terhadap bahan ajar kimia yang dikembangkan

\section{Metode Penelitian}

Metode penelitian pengembangan ini merujuk pada model pengembangan 4D yang dirumuskan oleh Thiagarajan et al. (1974). Alasan menggunakan model ini karena lebih sederhana, tidak rumit, sistematis, lebih spesifik serta mudah diikuti langkah-langkah pengembangannya. Tahapan pengembangan bahan ajar tersebut dijabarkan kedalam 4 langkah yaitu: (1) tahap pendefinisian (Define), (2) tahap perancangan (Design), (3) tahap pengembangan (Develop), (4) tahap penyebarluasan hasil pengembangan (Disseminate). Alur pengembangan yang dilakukan dalam penelitian ini, sampai tahap 3 (tahap pengembangan) dan dilakukan uji coba terbatas di SMAN 3 Malang.

Tahapan pendefinisian dilakukan melalui (a) analisis awal-akhir (front-end), (b) analisis karakteristik peserta didik, (c) analisis tugas, (d) analisis konsep, (e) perumusan tujuan pembelajaran dan (f) pendekatan pembelajaran. Pendekatan inkuiri terbimbing yang digunakan dalam pengembangan bahan ajar ini mengadaptasi tahapan pembelajaran Llewellyn (2002) yang dimodifikasi. Tahapan pembelajarannya meliputi 6 tahap yaitu (a) mengidentifikasi masalah, (b) merumuskan masalah (c) merumuskan hipotesis (d) mengumpulkan data, (e) menganalisis data, (f) menyimpulkan serta mengomunikasikan. Pada setiap tahap dalam kegiatan pembelajarannya terdapat kegiatan-kegiatan saintifik yang sesuai dengan kegiatan pembelajaran yang disarankan dalam kurikulum 2013. Tahapan pendefinisian dapat dilihat pada gambar 1 .

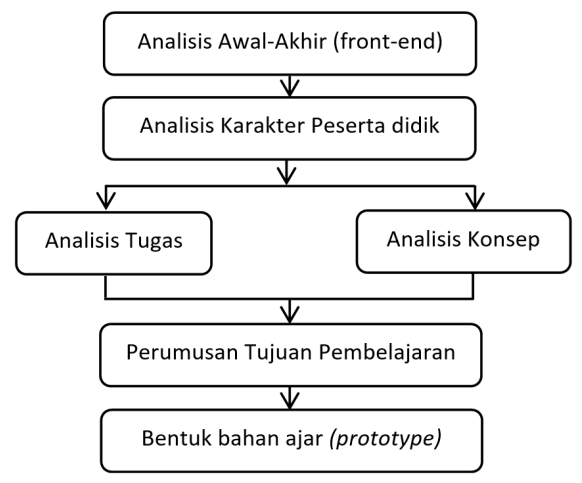

Gambar. 1 Bagan Tahap Pendefinisian (Define)

Pada tahap perancangan dihasilkan draf bahan ajar yang telah divalidasi oleh Ahli Isi. Selanjutnya draf bahan ajar dikembangkan 
pada tahap berikutnya. Tahapan pendefinisian ditunjukkan pada gambar 2 .

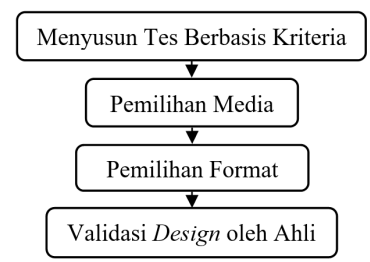

Gambar. 2 Bagan Tahap Perancangan (Design)

Tahap pengembangan menghasilkan bahan ajar yang layak digunakan dalam pembelajaran. Bahan ajar ini terlebih dahulu divalidasi oleh ahli isi/materi dan media pembelajaran. Uji validasi berpedoman pada standar kelayakan yang ditetapkan oleh BSNP meliputi kelayakan isi, kelayakan penyajian, kelayakan bahasa, dan kelayakan kegrafikan. Bahan ajar yang telah direvisi dengan dasar penilaian dari ahli dan telah dinyatakan layak, selanjutnya dilakukan diuji coba.

Uji coba bahan ajar hasil pengembangan ini dilakukan secara terbatas pada kelas XI IPA SMAN 3 Malang dengan menggunakan metode quasi experiment post test only group design. Tujuan uji coba ini untuk mengetahui efektivitas bahan ajar untuk meningkatkan kemampuan berpikir tingkat tinggi peserta didik dan respons peserta didik terhadap bahan ajar hasil pengembangan. Sampel penelitian terdiri dari kelas XI IPA (F-6) sebagai kelas kontrol dan XI IPA (E-6) sebagai kelas eksperimen. Rancangan penelitian eksperimen secara matematis dapat ditunjukkan pada Tabel 1.

Tabel 1. Skema Model Rancangan Penelitian

\begin{tabular}{cccc}
\hline Kelas & $\begin{array}{c}\text { Pre } \\
\text { tes }\end{array}$ & Perlakuan & $\begin{array}{c}\text { Post } \\
\text { tes }\end{array}$ \\
\hline Eksperimen & - & $\mathrm{X} 1$ & $\mathrm{O} 1$ \\
\hline Kontrol & - & $\mathrm{X} 2$ & $\mathrm{O} 1$ \\
\hline
\end{tabular}

Keterangan:

$\mathrm{X} 1=$ Pembelajaran dengan menggunakan bahan ajar hasil pengembangan

$\mathrm{X} 2=$ Pembelajaran dengan menggunakan bahan ajar yang dipakai di sekolah

$\mathrm{X} 3=$ Postes setelah kegiatan pembelajaran dengan menggunakan bahan ajar hasil pengembangan atau bahan ajar yang dipakai di sekolah

Instrumen uji efektivitas berupa soal pilihan ganda sebanyak 25 butir yang telah divalidasi isi, validasi butir soal, reliabilitas, daya beda dan tingkat kesukaran. Soal postes yang digunakan ditujukan untuk mengukur pemahaman konsep peserta didik terutama untuk konsep pada tingkatan analisis, evaluasi, dan sintesis pada ranah kognitif taksonomi bloom revisi. Efektifitas bahan ajar hasil pengembangan dilihat dari nilai postes setelah peserta didik menyelesaikan seluruh kegiatan pembelajaran menggunakan bahan ajar tersebut. Indikator yang digunakan dalam uji efektifitas adalah rerata nilai postes, uji t menggunakan independent sampel $\mathrm{t}$ test terhadap hasil postes kelas eksperimen dan kelas kontrol, serta jawaban peserta didik pada tiap tahap pada buku peserta didik. Bahan ajar hasil pengembangan dikatakan efektif jika rerata nilai postes kelas yang menggunakan bahan ajar hasil pengembangan lebih tinggi dibandingkan dengan kelas yang menggunakan bahan ajar lain yang ada disekolah (hasil uji $\mathrm{t}<0,05$ ), serta semua jawaban peserta didik sesuai dengan kunci pada buku guru yang menunjukkan peserta didik telah mampu mengikuti setiap tahapan pembelajaran. Respon peserta didik berupa penilaian, komentar, maupun saran setelah dibelajarkan dengan menggunakan bahan ajar hasil pengembangan. Respon peserta didik digunakan sebagai acuan untuk mengetahui persepsi peserta didik terhadap bahan ajar hasil pengembangan. Tahapan pendefinisian dapat dilihat pada gambar 3 .

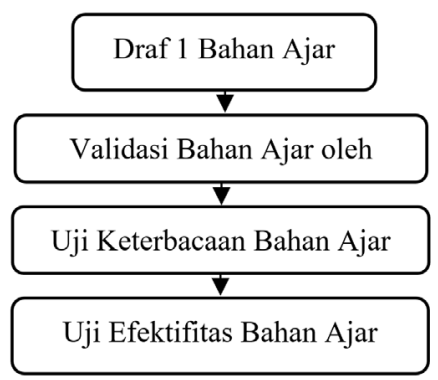

Gambar. 3 Bagan Tahap Pengembangan (Develop) 


\section{Hasil Penelitian dan Pembahasan}

Produk bahan ajar hasil pengembangan berupa buku guru dan buku siswa dalam bentuk cetak. Sistematika bahan ajar hasil pengembangan terdiri dari pra pendahuluan, pendahuluan, kegiatan pembelajaran, uji kompetensi, kunci jawaban uji kompetensi, glosarium dan daftar pustaka. Bahan ajar hasil pengembangan terdiri dari empat kegiatan pembelajaran, dimana setiap kegiatan pembelajaran berisi tujuan dan rencana pembelajaran. Pada tiap pembelajaran terdiri dari kegiatan pembelajaran, rangkuman, uji pemahaman dan umpan balik. Tahapan dalam pembelajarannya menggunakan model inkuiri terbimbing Lliwellyn yang terdiri dari enam tahap, yaitu: (1) Mengidentifikasi masalah, (2) Merumuskan masalah, (3) Merumuskan hipotesis, (4) Mengumpulkan data, (5) Menganalisis data, (6) Menyimpulkan dan mengomunikasikan. Setiap kegiatan pembelajaran dilengkapi dengan rubrik info kimia yang bertujuan untuk menambah pengetahuan dan memperluas wawasan peserta didik. Bahan ajar hasil pengembangan membantu guru untuk mengondisikan pembelajaran menjadi lebih menarik dan memotivasi peserta didik. Peserta didik dapat membangun konsepnya secara mandiri melalui pembelajaran yang dihubungkan dengan kehidupan sehari-hari sesuai dengan amanah kurikulum 2013.

Data yang diperoleh dalam penelitian ini berupa uji kelayakan, efektivitas serta respon peserta didik terhadap bahan ajar hasil pengembangan. Data hasil penelitian disajikan berikut ini.

\section{Hasil Validasi Kelayakan Bahan Ajar}

Tabel 2 berikut ini menyajikan hasil validasi kelayakan bahan ajar yang dilakukan oleh ahli isi/materi dan media pembelajaran terhadap bahan ajar berupa buku guru dan buku siswa.

Tabel 2 Hasil Validasi Kelayakan Bahan Ajar oleh Ahli

\begin{tabular}{|c|c|c|c|c|c|}
\hline No & Validator & $\begin{array}{c}\text { Buku guru } \\
(\%)\end{array}$ & $\begin{array}{c}\text { Buku siswa } \\
(\%)\end{array}$ & $\begin{array}{c}\text { Rata-rata } \\
(\%)\end{array}$ & Kriteria \\
\hline 1 & Ahli isi/materi Pembelajaran & 88.75 & 92,50 & 90,6 & $\begin{array}{l}\text { Sangat } \\
\text { layak }\end{array}$ \\
\hline 2 & Ahli Media Pembelajaran & 86,7 & 87,5 & 89.57 & $\begin{array}{l}\text { Sangat } \\
\text { layak }\end{array}$ \\
\hline Rata & -rata & 86,7 & 90,0 & 90,6 & $\begin{array}{l}\text { Sangat } \\
\text { layak }\end{array}$ \\
\hline
\end{tabular}

Tabel 3 Hasil Validasi Kelayakan Bahan Ajar oleh Ahli

\begin{tabular}{llllll}
\hline No & Aspek yang Dinilai & $\begin{array}{c}\text { Buku } \\
\text { Guru (\%) }\end{array}$ & $\begin{array}{c}\text { Buku siswa } \\
(\%)\end{array}$ & $\begin{array}{c}\text { Rata- } \\
\text { Rata }\end{array}$ & Kategori \\
\hline 1 & Isi/komponen bahan ajar & 2,85 & 91,6 & 92,22 & $\begin{array}{l}\text { Sangat } \\
\text { layak }\end{array}$ \\
\hline 2 & Tampilan/sajian & 87,5 & 93,3 & 90,4 & $\begin{array}{l}\text { Sangat } \\
\text { layak }\end{array}$ \\
\hline 3 & Bahasa & 87,5 & 92,6 & 90,05 & $\begin{array}{l}\text { Sangat } \\
\text { layak }\end{array}$ \\
\hline 4 & Kegrafisan & 81,85 & 91,6 & 86,73 & Layak \\
\hline & Rata-Rata & 87,4 & 92,27 & 89,83 & $\begin{array}{l}\text { Sangat } \\
\text { layak }\end{array}$ \\
\hline
\end{tabular}




\section{Hasil Uji Keterbacaan Bahan Ajar}

Hasil penilaian uji keterbacaan meliputi aspek kelayakan isi, kebahasaan, sajian, dan kegrafisan. Uji keterbacaan bahan ajar dilakukan oleh 2 orang guru kimia dan 6 orang peserta didik kelas XII IPA SMAN 3 Malang dengan komposisi 2 orang peserta didik berkemampuan tinggi, 2 orang peserta didik berkemampuan sedang dan 2 orang peserta didik berkemampuan rendah. Hasil uji keterbacaan bahan ajar disajikan pada Tabel 3 .

Uji efektivitas bahan ajar hasil pengembangan diukur dari hasil belajar dan respons peserta didik setelah menggunakan bahan ajar dalam pembelajaran. Hasil belajar tersebut dibandingkan dengan hasil belajar dari peserta didik yang dibelajarkan dengan bahan ajar lain (kelas kotrol). Hasil belajar peserta didik berupa nilai postes dari kelas eksperimen maupun kelas kontrol disajikan dalam Tabel 4. Hasil uji efektivitas yang disajikan pada Tabel 4 menunjukkan rerata nilai postes kelas eksperimen lebih tinggi dibandingkan dengan kelas kontrol. Hasil analisis uji independent sampel $\mathrm{t}$ test didapatkan nilai signifikansi (2-tailed) sebesar 0,012<0,05 yang berarti bahwa ada perbedaan yang signifikan antara kelas eksperimen dan kelas kontrol.

Tabel 4. Hasil Perolehan Nilai Postes Kelas Eksperimen dan Kelas Kontrol

\begin{tabular}{clc}
\hline No & $\begin{array}{c}\text { Uji Lapangan } \\
\text { Terbatas }\end{array}$ & $\begin{array}{c}\text { Rata-rata } \\
\text { Nilai Postes }\end{array}$ \\
\hline 1 & Kelas Kontrol & 85,21 \\
\hline 2 & Kelas Eksperimen & 87,85 \\
\hline
\end{tabular}

Setelah kegiatan pembelajaran, peserta didik memberikan persepsi terhadap bahan ajar hasil pengembangan yang digunakan. Persepsi peserta didik terhadap bahan ajar hasil pengembangan disajikan dalam Tabel 5.

\section{Pembahasan}

Berdasarkan data pada Tabel 2 rata-rata hasil validasi kelayakan bahan ajar oleh ahli isi atau materi dan ahli media pembelajaran terhadap bahan ajar berupa buku guru adalah sebesar $86,7 \%$ dan buku siswa sebesar $90 \%$ dengan kategori sangat layak. Kriteria penilaian tersebut meliputi kelayakan isi/materi, kelayakan sajian, kelayakan kebahasaan dan kelayakan kegrafisan. Dari hasil validasi tersebut dapat dikatakan bahwa secara umum bahan ajar hasil pengembangan yang berupa buku guru dan buku siswa sangat layak untuk digunakan dalam kegiatan pembelajaran. Hal ini dikarenakan dari segi isi/materi bahan ajar menyajikan konten yang sesuai dengan kompetensi dasar yang terdapat dalam kurikulum. Kebenaran konsep dan penyajian materi yang terstruktur akan memudahkan peserta didik dalam membentuk konsep. Tampilan bahan ajar yang tidak monoton (colourfull) didukung gambar yang diambil dari kehidupan sehari-hari dan video yang relevan menjadikan pembelajaran lebih menarik.

Berdasarkan Tabel 3 diketahui bahwa hasil uji keterbacaan pengguna bahan ajar hasil pengembangan baik yang dilakukan oleh guru maupun peserta didik menunjukkan rata-rata nilai sebesar 89,83\% dengan kategori sangat layak. Kelayakan bahan ajar tersebut dikarenakan komponen-komponen yang terdapat dalam bahan ajar disajikan secara sistematis. Materi yang disampaikan diuraikan secara singkat dan jelas, sesuai dengan kompetensi dasar dalam kurikulum. Pada tiap akhir pembelajaran peserta didik menyimpulkan dan menyusun peta konsep untuk mengetahui pemahaman peserta didik. Aspek tampilan atau sajian, bahan ajar menyajikan materi yang didukung

Tabel 5. Hasil Respon Peserta didik Terhadap Bahan Ajar Hasil Pengembangan

\begin{tabular}{llcl}
\hline No & Aspek yang Dinilai & Rata-Rata Hasil Penilaian (\%) & \multicolumn{1}{c}{ Kriteria } \\
\hline 1 & Isi/komponen bahan ajar & 86 & Sangat baik \\
\hline 2 & Sajian & 86 & Sangat menarik \\
\hline 3 & Kebahasaan & 86,6 & Sangat mudah \\
\hline 4 & Kegrafisan & 90,3 & Sangat menarik \\
\hline & Rata-rata & 87,23 & Sangat baik \\
\hline
\end{tabular}


dengan contoh aplikatif sehingga mendorong peserta didik untuk mempelajari lebih lanjut. Materi laju reaksi yang dihubungkan dengan kehidupan sehari-hari lebih memotivasi peserta didik untuk mengetahui manfaat belajar kimia. Sajian pendahuluan yang interaktif merangsang rasa ingin tahu peserta didik. Penggunaan bahasa yang komunikatif, dan sesuai dengan kaidah bahasa Indonesia yang baik dan benar memberikan kemudahan peserta didik dalam memahami materi. Penampilan cover yang menarik, penggunaan jenis huruf dan ukuran yang tepat, tata letak (lay out) yang sesuai, ilustrasi gambar dan video yang relevan serta pemilihan warna yang tidak menyebabkan lelah ketika membaca menimbulkan minat bagi pengguna untuk membacanya.

Berdasarkan hasil analisis jawaban peserta didik pada buku siswa, disimpulkan bahwa bahan ajar hasil pengembangan sangat efektif digunakan dalam kegiatan pembelajaran. Setiap jawaban peserta didik menunjukkan peserta didik mampu menganalisis, mengevaluasi, dan mensintesis. Kemampuan berpikir pada tingkat ini menunjukkan peningkatan kemampuan berpikir tingkat tinggi peserta didik.

Keefektifan ini dikarenakan bahan ajar hasil pengembangan menyajikan uraian materi yang terstruktur, menuntun peserta didik untuk membangun konsepnya secara mandiri melalui tahapan-tahapan pembelajarannya serta terintegrasi dengan kehidupan seharihari, sehingga memberikan kesempatan kepada peserta didik dalam mendapatkan konsep secara lebih baik. Aplikasi dari konsep yang dipelajari dirancang agar peserta didik mengerti arti pentingnya belajar kimia. Penggunaan pendekatan inkuiri terbimbing melatih peserta didik untuk dapat memecahkan masalah pada tingkat menganalisis, mengevaluasi, dan mensintesis. Pembentukan konsep yang baik ditunjukkan dengan jawaban pada uji pemahaman yang diberikan oleh peserta didik.

Persepsi peserta didik terhadap bahan ajar hasil pengembangan yang disajikan pada Tabel 5 menunjukkan bahwa bahan ajar hasil pengembangan sangat baik. Peserta didik memberikan respons dari segi isi/komponennya sangat baik, sajiannya sangat menarik, bahasanya sangat mudah, dan desain grafisnya sangat menarik. Oleh karena itu, peserta didik sangat tertarik untuk menggunakannya. Bahan ajar yang mudah digunakan akan meningkatkan minat peserta didik dalam belajar kimia.

Berdasarkan uraian pembahasan, beberapa kelebihan dari bahan ajar hasil pengembangan yaitu (1) Bahan ajar hasil pengembangan menyajikan materi kimia yang terintegrasi dengan kehidupan sehari-hari, sehingga peserta didik SMA memiliki minat dan mengerti arti pentingnya belajar kimia. (2) Bahan ajar hasil pengembangan telah dinyatakan layak dan terbukti efektif digunakan dalam kegiatan pembelajaran. (3) Bahan ajar hasil pengembangan disajikan melalui tahapan pembelajaran yang memberikan pengalaman belajar kepada peserta didik untuk membentuk konsep sehingga peserta didik dapat memahami materi belajarnya secara sistematis. (4) Bahan ajar hasil pengembangan berorientasi pada pemahaman konsep sehingga dapat meningkatkan hasil belajar peserta didik. (5) Bahan ajar hasil pengembangan dapat digunakan baik dalam kegiatan pembelajaran di kelas maupun di luar kelas (mandiri).

Kelemahan yang ditemui ketika uji efektivitas adalah waktu yang direncanakan dalam kegiatan pembelajaran kurang mencukupi. Hal ini dikarenakan peserta didik belum terbiasa dengan pembelajaran model ini, sehingga diawal pertemuan membutuhkan waktu untuk menjelaskan pada peserta didik bagaimana dan apa yang harus dikerjakan oleh peserta didik dalam pembelajaran. Kondisi ini yang memberikan informasi bahwa peserta didik memerlukan bimbingan guru dalam menggunakan bahan ajar.

\section{Kesimpulan dan Saran Kesimpulan}

Berdasarkan pembahasan di atas, penelitian pengembangan ini dapat disimpulkan hal-hal sebagai berikut.

1. Telah dihasilkan bahan ajar laju reaksi dengan pendekatan inkuiri terbimbing untuk peserta didik SMA kelas XI IPA berdasarkan hasil penilaian ahli. Hasil penilaian dinyatakan layak ditinjau dari 
segi isi atau materi, sajian, kebahasaan, dan kegrafisan, untuk digunakan dalam kegiatan pembelajaran.

2. Bahan ajar laju reaksi hasil pengembangan terbukti efektif dalam meningkatkan hasil belajar peserta didik dan meningkatkan kemampuan berpikir tingkat tinggi peserta didik (HOTS).

3. Secara umum peserta didik memberikan persepsi positif terhadap bahan ajar hasil pengembangan yang ditunjukkan dengan ketertarikan dan kemudahan peserta didik dalam menggunakannya.

\section{Saran}

Berdasarkan pembahasan yang telah diuraikan, saran yang dapat diberikan adalah: (1) Guru memberikan bimbingan kepada peserta didik dalam menggunakan bahan ajar hasil pengembangan, sehingga peserta didik tidak mengalami kesulitan. (2) Pembentukan kelompok diskusi yang memiliki kemampuan kognitif yang heterogen dan merata sehingga kegiatan diskusi dapat berjalan dengan baik. (3) Guru memberikan pengawasan dan penguatan konsep kepada peserta didik agar terbiasa menggunakan bahan ajar. (4) Bahan ajar hasil pengembangan didukung oleh penggunaan literatur yang berasal dari internet yang relevan dengan topik pembelajaran dan merupakan aplikasinya dalam kehidupan sehari-hari, hendaknya dimanfaatkan semaksimal mungkin agar peserta didik mendapatkan tambahan informasi dan pengetahuan sehingga memperluas wawasan peserta didik tentang ilmu kimia. (5) Pengujian lapangan terbatas hanya melibatkan satu kelas saja maka diperlukan pengujian lebih lanjut pada lingkup satu sekolah sebelum dilakukan diseminasi produk pengembangan lebih luas. (6) Bahan ajar hasil pengembangan hanya terbatas pada materi laju reaksi sehingga perlu dikembangkan materi kimia lain khususnya pada materimateri yang merupakan prasyarat untuk materi yang lain. (7) Bahan ajar ini dikembangkan dengan pendekatan inkuiri terbimbing sehingga perlu dikembangkan bahan ajar dengan variasi pendekatan yang lain agar tersedia bahan ajar yang lebih lengkap.

\section{Daftar Rujukan}

Akbar, Sa'dun. (2013). Instrumen Perangkat Pembelajaran. Bandung: Remaja Rosdakarya

Aksela. M. (2005). Supporting Meaningful Chemistry Learning and Higher-Order Thinking Throgh Computer-Assisted Inquiry: A Design Research Approach.

Bloom, B. S, Engelhart, M. D, Furst, E. J, Hill, W. H \& Krathwohl, D. R, (1956). Taxonomy of educational objectives: Handbook I: Cognitive domain. New York: David McKay

Direktorat Tenaga Kependidikan. (2008). Panduan Penulisan Modul. Jakarta: Departemen Pendidikan Nasional.

Dirjen Pengembangan SMA. (2010). Petunjuk Teknis Pengembangan Bahan Ajar SMA. Jakarta: Depdiknas

Fitria, C, D, Muntholib, \& Aman. (2013). Pengembangan Bahan Ajar Materi Larutan Penyangga, Hidrolisis Garam, Dan Kelarutan dan Hasil Kali Kelarutan Menggunakan Model Pembelajaran Learning Cycle 5E Untuk Siswa SMA/ MA. Jurnal elektronik Universitas Negeri Malang 2 (2)

Gafur, A. (1994). Desain Instruksional. Bandung: Citra Aditya Bakti

Kementrian Pendidikan dan Kebudayaan (2013). Peraturan Menteri Pendidikan dan Kebudayaan No.69 Tahun 2013. Jakarta: Kementrian Pendidikan dan Kebudayaan.

Llewellyn, D. (2005). Teaching High School Science Through Inquiry. California: Corwin Press.

Prananda, O. (2013). Menggali Pemahaman Peserta didik Sma Pada Konsep Laju Reaksi Dengan Menggunakan Instrumen Diagnostik Two-Tier. Skripsi tidak diterbitkan. Malang: UM.

Putri, Y. M. D. (2013). Pengaruh Metode Pembelajaran Inkuiri Terbimbing (Guided Inquiry) untuk Meningkatkan Hasil Belajar dan Kemampuan Berpikir Tingkat Tinggi (High Order Thinking Skill) Peserta 
didik Kelas X SMA Negeri 1 Malang Pada Pokok Bahasan Hidrokarbon. Skripsi tidak diterbitkan. Malang: UM

Thiagarajan, S., Dorothy, S., Melvyn, I., \& Semmel. (1974). Instructional Development for training Teachers Of Exceptional Children. Blomington Indiana: Indiana University.

Vlassi, M., \& Karaliota, A. (2013). The Comparison Between Guided Inquiry and Traditional Teaching Method. A Case Study for The Teaching of The Structure of Matter to 8th Grade Greek Students. Procedia - Social and Behavioral Science, Vol.93: 494-497. 